\title{
Is the United Nations Organization an Obstruction in the Changing World?
}

\author{
Aslan Abashidze \\ Honored Lawyer of Russia, Head of the Department of International Law of the RUDN University, Member of the UN \\ Committee on economic, social and cultural rights, Chairman of the International Law Commission of the United Nations \\ Association of Russia, Doctor of Law, Professor \\ Moscow, Russia \\ Abashidze_AKh@rudn.university
}

\begin{abstract}
The question posed in the title of the article is not contrived. We can often hear it from politicians, journalists, humanitarian experts. Indeed, you can pick and name a lot of arguments, facts and circumstances that would justify such concern. A universal intergovernmental organization of general and special competence is needed. This is the UN and its specialized agencies, which form the UN system. To strengthen this system, it is necessary that the provisions of the UN Charter be viewed as an integral and important part of the common international law.
\end{abstract}

\section{Keywords-UN; international law}

\section{INTRODUCTION}

The question posed in the title of the article is not contrived. We can often hear it from politicians, journalists, humanitarian experts. Indeed, you can pick and name a lot of arguments, facts and circumstances that would justify such concern. The answer to this question can be twofold: "yes" or "no". However, when you answer "no", you need powerful counterarguments, and when you answer "yes", another question arises: what can be offered instead of the United Nations (UN)?

For any of these answers, it is necessary to disclose the characteristic features of the changing world that can highlight the main trends in the development of international relations, and the global problems, solution of which is the objective of the United Nations, as defined in Art. 1 para. 4 of its constituent instrument - the Charter: "To be a center for harmonizing the actions of nations in the attainment of ... common ends".

\section{THEORETICAL GROUNDS OF THE RESEARCH}

Changes in the world are conditioned by various factors, especially the consequences of globalization and the growing number of new threats and challenges. The changing world is perceived in different ways in the studies conducted within or under the auspices of the United Nations and at the scholar level.

The Global Risks Report 2017, which was published before the World Economic Forum in Davos, lists five categories of global risks: economic, ecological, geopolitical, social and technological. The report also lists and analyzes 10 specific types of these five categories of global risks: weapons of mass destruction; extreme weather conditions; water crisis; natural disasters; failure in climate change; forced migration on a large scale; food crisis; terrorist attacks; interstate conflict unemployment ${ }^{1}$.

This brings up a logical question: what characterizes the current "changing world"? What is implied in the phrase indicated in the title of this article? Perhaps, comparing with the past, the current changes are manifested in the increasing interconnection of countries, for example, in a global network, the use of which can make even the world's leading powers vulnerable (in particular, in case of "cyber attacks")? Whatever arguments or statistics we cite here, we still come to the fact that we recognize the need for joint actions by all states in order to overcome the main negative trends and problems caused by the process of globalization and other factors. In this situation, from the point of view of methodology, it is necessary to change the context of the subject of discussion and try to answer the main question posed by a preliminary answer to another question: who is the main subject of policy development and the conductor of the relevant actions in the context of globalization?

It is important to pay attention to the destructive actions that have been undertaken by some Western leading powers since the beginning of the UN activities in accordance (as it seemed) with the provisions of the UN Charter, including Chapter VIII of the UN Charter ("regional arrangements") and its Art. 52, para. 1 of which reads: "Nothing in the present Charter precludes the existence of regional arrangements or agencies for dealing with such matters relating to the maintenance of international peace and security..." These destructive actions were led by the United States and Great Britain - two of the three powers that determined the post-war world order based on the UN Charter.

To confirm the above-said, we will give examples from various spheres. In 1949, NATO was established (North Atlantic Treaty Organization). According to the preamble of

${ }^{1}$ See: World Economic Forum. The Global Risks Report 2017, 12th Edition. Geneva, 2017. URL: https://www.weforum.org/reports/the-global-risksreport-2017 (as of 20.01.2017). 
the NATO Charter, "the Parties to this Treaty reaffirm their faith in the purposes and principles of the Charter of the United Nations and their desire to live in peace with all peoples and all governments".

In accordance with Art. 1 of the Charter, they "undertake, as set forth in the Charter of the United Nations, to settle any international dispute in which they may be involved by peaceful means in such a manner that international peace and security and justice are not endangered, and to refrain in their international relations from the threat or use of force in any manner inconsistent with the purposes of the United Nations".

However, eight years after the collapse of the USSR and the end of the Cold War, that is, in 1999, NATO modified the provisions of its Charter and extended its interests to the global level. The United States began to use NATO as a means to establish a unipolar world and punish leaders of countries that did not fit into the "scenarios" of the US national policy, such as Slobodan Milosevic (Yugoslavia), Saddam Hussein (Iraq), Muammar Gaddafi (Libya), Bashar Assad (Syria) and others. The administration of US President Barack Obama was so "carried away" that the president of Turkey, a country that is a member of NATO, accused the US authorities of attempting a coup d'état. In order to overthrow Bashar Assad's regime in Syria, the Pentagon, the CIA and other US special services began to create new ones and help terrorist groups led by the so-called ISIS ${ }^{2}$.

The US withdrew from the ABM Treaty and placed various NATO military components in Eastern European states that should not have been used in this capacity in accordance with the "gentlemen's" agreements reached by the USSR leadership with the NATO leadership during the negotiations on unification of Germany and withdrawal of Soviet troops from the Eastern European states. These same states wanted Russia to unilaterally limit its military potential in the CFE Treaty [1].

Another example is related to the sphere of human rights, in which the UN succeeded more than other areas of its activity. As a result of the undertaken reform, new mechanisms are being implemented in the form of the Universal Periodic Review (UPR) ${ }^{3}$, the shortcomings of the UN Commission on Human Rights have been taken into account, and it has been replaced by the UN Human Rights Council (HRC). The potential of the United Nations High Commissioner for Human Rights has been significantly strengthened, and it becomes the center for coordination of the human rights activities of the UN system. A system of human rights treaty bodies has been established that covers all basic human rights and freedoms, and an intergovernmental process

\footnotetext{
${ }^{2}$ The Islamic State (also known as: the Islamic State of Iraq and Syria, the Islamic State of Iraq and the Levant, the Islamic State of Iraq and al-Sham) terrorist organization banned in Russia on the basis of the decision of the Supreme Court of the Russian Federation No. AKPI No. 14-1424C of December 29, 2014 (entered into force on February 13, 2015) // The unified federal list of organizations, including foreign and international organizations, recognized as terrorist in accordance with the legislation of the Russian Federation / website of the FSB of Russia. URL: http://www.fsb.ru/fsb/npd/terror.htm (as of 20.01.2017).

${ }^{3}$ See: A.K. Abashidze, A.O. Goltyaev. Universal mechanisms for protection of human rights. M: UNITY-DANA, 2013.
}

to strengthen it was launched in 2014. In 1993, the Vienna UN Conference on Human Rights reaffirmed the principle of the universality, indivisibility and interconnectedness of human rights and fundamental freedoms.

Unfortunately, all this potential is not used to improve the conditions for people to exercise their rights wherever they live, but to meet interests of the Western states, which considerably contradict the purposes and principles of the UN Charter and the main international human rights treaties. This is evident in many respects, which is also pointed out by Western representatives of non-governmental organizations. For example, in November 2015, a representative of The Global Initiative for Economic, Social and Cultural Rights, Lucy McKernan posted her article on the website of The Universal Rights Group, in which she rightly noted the persistence of the previous negative trend reflected in underestimation of importance of economic, social and cultural human rights in comparison with civil and political rights, which, in her opinion, is due to inadequate political and financial support of the states, fewer resolutions on economic, social and cultural issues adopted by the main and functional UN bodies, fewer special procedures of the UN Human Rights Council (HRC) than special procedures on civil and political rights, to which the HRC pays more attention [2]. This is a mirroring of the policy of the United States and its allies. The United States is the only country not participating in the 1989 United Nations Convention on the Rights of the Child. The United States is one of the 20 member states of the United Nations that do not participate in the International Covenant on Economic, Social and Cultural Rights. At the same time, it was the administration of the former US president who "tried" to prevent inclusion of Russia into the current composition of the HRC, but included such "democratic" states as the US itself, Saudi Arabia and others.

Representatives of Western states launched a broad campaign to introduce "new" elements into the UN human rights system under the guise of strengthening the principle of non-discrimination by introducing "new anti-discrimination features" such as "sexual orientation" and "gender identity".

The new administration of US President D. Trump made a statement and is already taking the first steps to get rid of the "legacy" of the former administration of President Barack Obama. In particular, the reduction of the US contributions to the regular budget of the United Nations was announced; the total budget of the United Nations for 2016-2017 fiscal years is USD 5.6 billion, $22 \%$ of which (USD 810.837 million) are the contributions of the USA. The amount of contributions to the UN regular budget from other member states is the following: Japan (9.68\%), China (7.921\%), Germany $(6.389 \%)$, France $(4.859 \%)$, Great Britain (4.63\%), Brazil $(3.823 \%)$, etc.

All this "activity" of the United States ended with the country's withdrawal from the UN Human Rights Council, which was condemned by the UN Secretary General, EU member states, well-known NGOs (including Human Rights Watch).

The question arises: how will the reduction in the amount of contributions from the United States affect the activities of 
the United Nations? If we take into account the fact that the burden on the entire UN system is growing due to emergence of new problems, shortage of financial resources will undoubtedly impair the efficiency of its activities. However, given the unjustified growth of the UN bureaucracy caused by an ever-increasing number of Western representatives, and creation of structures within the UN imposed by Western states (for example, the Special Rapporteur on LGBT issues, etc.), the deficit in the UN budget will lead to a reduction of unnecessary and inefficient UN structures.

Recently there has been an intensification of attempts to reformat regional, interregional and subregional associations in various spheres of state cooperation: crisis in the EU, the US withdrawal from the NAFTA and the failed Transatlantic Trade and Investment Partnership, strengthening of the Eurasian Union, slowing of the pace of cooperation within the BRICS framework, the ill-considered steps to expand NATO, etc. Such tendencies are typical for the current unstable state of international relations, they will continue to exist, but they cannot fulfill the role assigned to the UN - to be a center for coordinating joint actions of states at the global level to solve global problems and confront global challenges, threats and risks. In the long term, the United Nations has no alternative. This means that we only need to talk about adapting the UN structures to the needs of the "changing world", where sovereign states still remain the key actors both in the development of joint actions and in their implementation, which implies that they have a conscious political will and readiness to act on the basis of the system of collective security and cooperation established by the UN Charter.

\section{CONCLUSION}

Everything that happens in international relations and world politics confirms the opinion of the famous Western legal scholar, professor L. Oppenheim, who saw the binding force of international law in the consent of states or in the selfrestraint of sovereign states [3]. Financial crisis, economic recession and other problems cannot be overcome by efforts undertaken within the framework of individual integration associations: the EU, which is having difficulty today overcoming domestic political problems, can be brought in evidence of this statement. A universal intergovernmental organization of general and special competence is needed. This is the UN and its specialized agencies, which form the UN system. To strengthen this system, it is necessary that the provisions of the UN Charter be viewed as an integral and important part of the common international law, which involves changing the approaches of the Western science of international law to key aspects of the system of collective security and contemporary international law.

\section{ACKNOWLEDGMENT}

The paper is prepared under the project N 16-18-10315 funded by Russian Science Foundation at Saint Petersburg State University.

\section{REFERENCES}

[1] A.K. Abashidze. International legal issues arising due to suspension of Russia's participation in the CFE Treaty // Bulletin of the People's Friendship University of Russia. Series: legal sciences. 2008. No. 1. P. 70-77.

[2] McKernan L. Economic, social and cultural rights: exploding myths and building consensus // URL: http://www.universalrights.org/blog/economic-social-and-cultural-rights-exploding-mythsand-building-consensus/ (as of November 19, 2015).

[3] Oppenheim L. The Science of International Law: Its Task and Method // American Journal of International Law. Vol. 2. 1908. P. 55-56. 